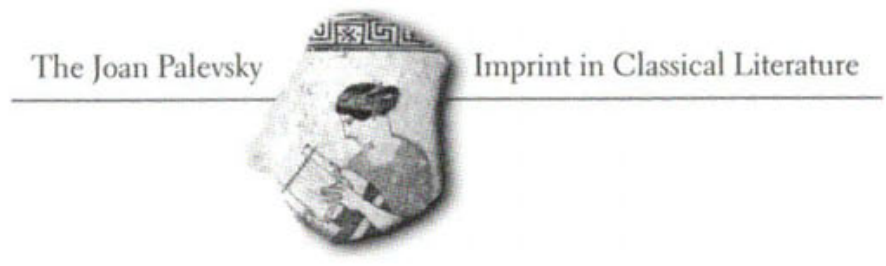

In honor of beloved Virgil-

“O degli altri poeti onore e lume ..."

-Dante, Inferno 
The publisher gratefully acknowledges the generous contribution to this book provided by Joan Palevsky 
The School of History

๒コロصロロコロ 


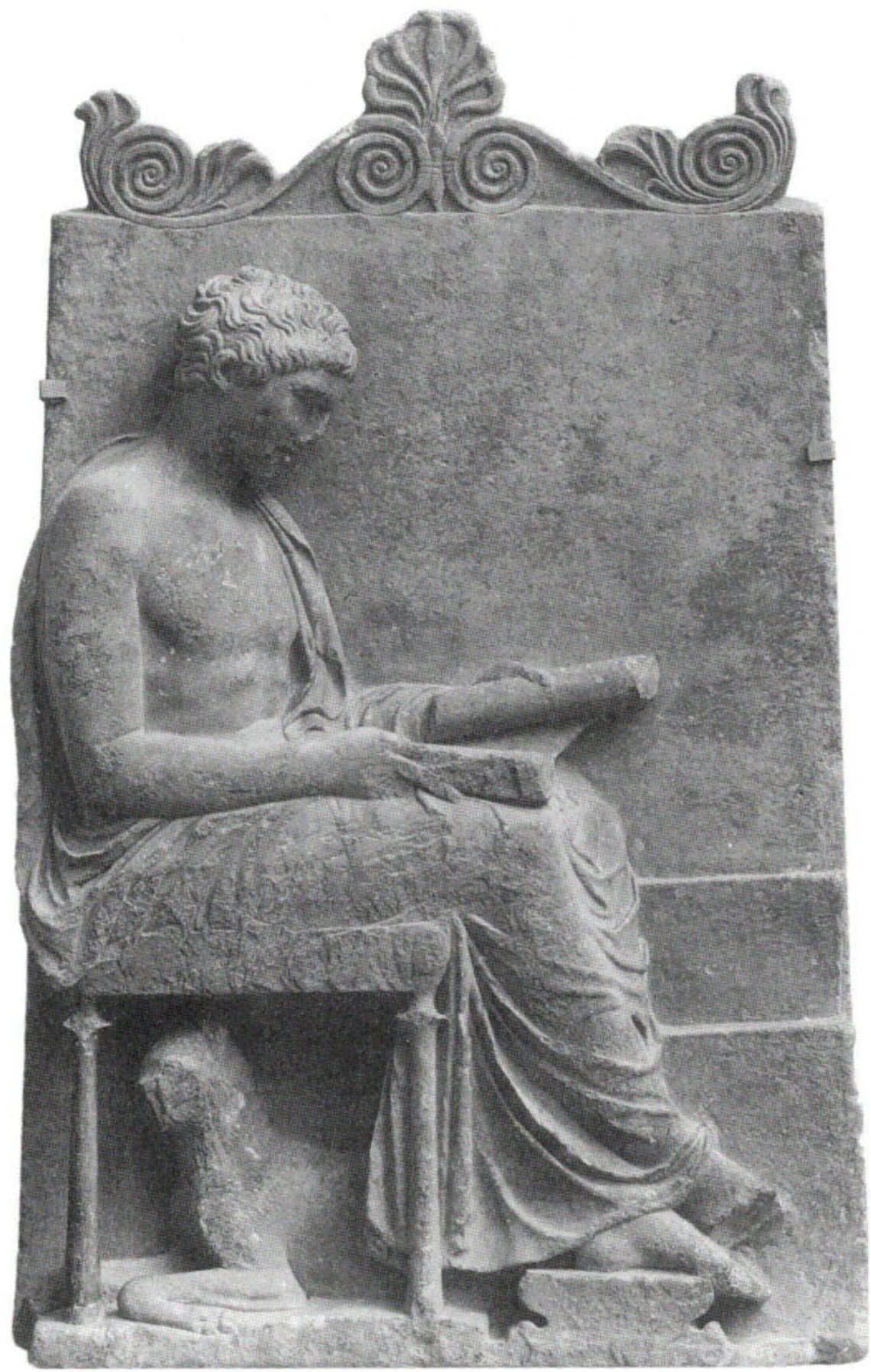

Studious arete: Athenian grave relief of youth reading book- roll, ca. 4 oo. Grottaferrata abbey, Rome. Photo courtesy of the Deutsches Archäologisches Institut, Rome, neg. no. 61.173. 


\section{The School of History}

Athens in the Age of Socrates

๒コロコロコロロ

Mark Munn

UNIVERSITY OF CALIFORNIA PRESS

Berkeley Los Angeles London 
University of California Press

Berkeley and Los Angeles, California

University of California Press, Ltd.

London, England

(C) 2000 by the Regents of the University of California

Library of Congress Cataloging-in-Publication Data

Munn, Mark Henderson.

The school of history: Athens in the age of Socrates / by Mark Munn.

p. $\quad \mathrm{cm}$.

Includes bibliographical references and index.

ISBN 0-520-2 $1557-5$ (cloth : alk paper)

1. Athens (Greece)-Civilization-Political aspects. 2. Greece-HistoryAthenian supremacy, 479-431 B.C. 3. Democracy-Greece-AthensHistoriography. I. Title.

DF277.M86 2000

$93^{\prime} .04-\mathrm{dc} 21$

$99^{-0} 4^{6} 45^{1}$

Manufactured in the United States of America

$\begin{array}{llllllllllllllllllll}08 & 07 & 06 & 05 & 04 & 03 & 02 & 01 & 00 & 99 & 10 & 9 & 8 & 7 & 6 & 5 & 4 & 3 & 2 & 1\end{array}$

The paper used in this publication meets the minimum requirements of ANSI / NISO

Z39.48-1992 (R 1997) (Permanence of Paper). @ 
For my parents,

Robert Henderson Munn and Ethel Marie Bianucci Munn, with love and thanks

for the best of beginnings 
